say that as a result of the Orkney enquiry and our recent success in Shetland we feel that it is time to amend the legislation in respect of the establishment of mink farms in hitherto mink-free areas and that is where we now intend to redirect our efforts.

Once again, many thanks.

Yours faithfully, Gillian Okill,

Secretary, Shetland Bird Club, Heilinabretta, Cauldhame,

Trondra, Shetland

ffPS was among many conservation organisations and individuals that joined in the protest against an application to build a mink farm on Trondra in the Shetland Islands. The Shetland Islands Council rejected the application in October 1983. Among the objections to the proposal the one of particular concem to ffPS was the high risk of mink escaping and establishing in the wild to become a threat to wildlife, especially to ground-nesting birds.

Editor

\section{Fea's muntjac}

I took this photograph of Muntiacus feae in the Dusit Zoo in Bangkok in the late 1970s. It is a female and easily identified, being darker than the many Indian races with yellow hairs on the crown, and with a distinct black line running up the centre of the pedicle.

The director, Mr Chira Mockvichai, wrote to me in 1981 to tell me that they had not succeeded in obtaining a male, but I later learnt that two more females had been captured, and it is hoped eventually to start a breeding herd there.

This rare form occurs in Tenasserim and southwest Thailand, and it is surprising that the Chinese have found it such a long way from its known range. There are, of course, a number of species and races of muntjac known from China.

\section{Yours sincerely, James Hancock, 'Brookside', Back Street, St Cross, Winchester S023 9SB, UK}

In the January issue of Oryx (page 5), we published a report that Fea's muntjac had been discovered for the first time in China. I added that, according to the IUCN Mammal Red Data Book (1972), there were no known captive specimens.

Editor

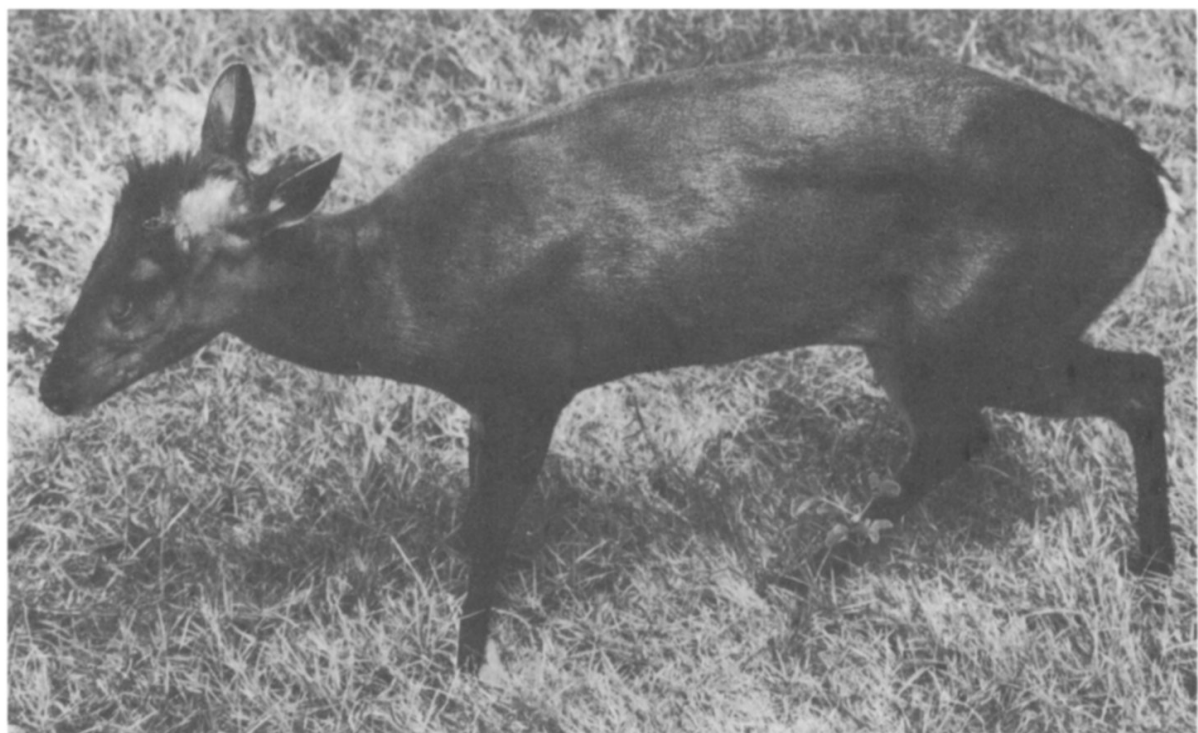

